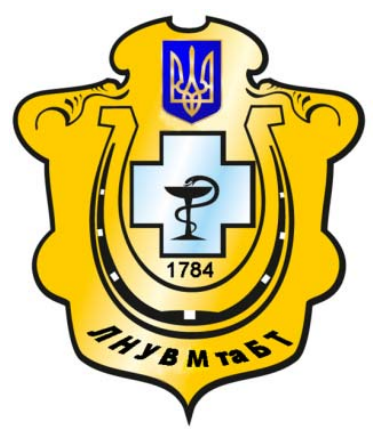

Науковий вісник Львівського національного університету ветеринарної медицини та біотехнологій імені С.3. Гжицького

Scientific Messenger of Lviv National University of Veterinary Medicine and Biotechnologies named after S.Z. Gzhytskyj

doi:10.15421/nvlvet6801

ISSN 2413-5550 print

ISSN 2518-1327 online

$\underline{\text { http://nvlvet.com.ua/ }}$

УДК 664.3

\title{
Виявлення фальсифікації жирової сировини у виробництві комбінованих харчових продуктів
}

\author{
Арсеньєва Л.Ю., В.М. Мельниченко \\ tori-1309@ukr.net
}

Національний університет харчових технологій,

вул. Володимирська, 68, м. Київ, 01601, Украӥна

\begin{abstract}
Стаття присвячена проведенню газохроматографічного аналізу жирнокислотного складу різних видів жирів, які використовуються у виробничтві кондитерських і хлібобулочних виробів. Визначення фальсифікації жирової сировини в борошняних кондитерських виробах проводили за жирнокислотним складом жиру після випікання. Для ивого визначали жирнокислотний склад сировини, яка використовувалась, і його зміни уже в готовому продукті. Дослідження проводили з маслом селянським солодко вериковим з вмістом жиру 73\% та маргарином столовим «молочним» жирністю не менше 82\%. Особлива увага присвячена визначенню змін жиру, що відбуваються під час термічного оброблення. Крім того, наведено ряд кислот, які вказують на фальсифікацію сировини. На основі аналізу було ідентифіковано олії, які використовувались для приготування жирів, взятих на дослідження - кокосова, арахісова, соєва та соняшникова. Проведено удосконалення методики вилучення жиру з готового продукту. Основний зміст дослідження складає аналіз зміни жирнокислотного складу, що відбуваються після термічного оброблення. Результати дослідження висвітлюють, що кожному виду жиру притаманні свої індивідуальні зміни жирнокислотного складу Ця проблема мало вивчена і вимагає детальнішого дослідження.

Ключові слова: газова хроматографія, жирнокислотний склад, харчові жири, олії, масло верикове, маргарин, фальсифікачія жиру, окислення, термічна обробка, хлібобулочні вироби.
\end{abstract}

\section{Выявление фальсификации жирового сырья в производстве комбиниро- ванных пищевых продуктов}

\author{
Л.Ю. Арсеньева, В.Н. Мельниченко \\ tori-1309@ukr.net
}

Национальный университет пищевых технологий, ул. Владимирская, 68, г. Киев, 01601, Украина

\begin{abstract}
Даная статья посвящена проведению газохроматографического анализа жирнокислотного состава различных видов жиров, используемых в производстве кондитерских и хлебобулочных изделий. Определение фальсификации жирового сырья в мучных кондитерских изделиях проводили по жирнокислотному составу жира после выпечки. Для этого определяли жирнокислотный состав сырья, которае использовалось, и его изменения уже в готовом продукте. Исследования проводили с крестьянским маслом сладко-сливочным с содержанием жира 73\% и маргарином столовым «молочным» жирностью не менее $82 \%$. Особое внимание посвящено определению изменений жира, происходящие во время термической обработки. Кроме того, приведен ряд кислот, которые указывают на фальсификаиию сырья. На основе анализа было идентифицировано растительные масла, которые использовались для приготовления жиров, взятых на исследование - кокосовое, арахисовое, соевое и подсолнечное. Проведено усовершенствование методики извлечения жира из готового продукта. Основное содержсание исследования составляет анализ изменения жирнокислотного состава, которые происходят после термической обработки. Результаты исследования освещают, что каждому виду жира присущи свои индивидуальные изменения жирнокислотного состава. Эта проблема мало изучена и требует более детального исследования.
\end{abstract}

Citation:

Arsen'eva, L.Y., Melnychenko, V.N. (2016). Determination of fatty acid sladu different fats and changes during heat treatment. Scientific Messenger LNUVMBT named after S.Z. Gzhytskyj, 18, 2(68), 3-6. 
Ключевые слова: газовая хроматография, жирнокислотный состав, пищевые жиры, растительные масла, масло сливочное, маргарин, фальсификачия жира, окисление, термическая обработка, хлебобулочные изделия.

\title{
Determination of fatty acid sladu different fats and changes during heat treatment
}

\author{
L.Y. Arsen'eva, V.N. Melnychenko \\ tori-1309@ukr.net \\ National University of Food Technologies, \\ Volodymyrska Str., 68, Kyiv, 01601, Ukraine
}

The article is sanctified to realization of chromatographic analysis of fatty acid composition of different types of fats, that is used in the production of pastry and bakery wares. Determinations of falsification of fatty raw material in flour pastry wares conducted after fatty acid composition of fat after baking. For this purpose determined fatty acid composition of raw material that was used, and his change, already in the prepared product. Researches conducted with butter a peasant sweetly creamy with content of fat $73 \%$ a margarine is table «milk» an adiposeness not less than $82 \%$. The special attention is sanctified to determination of changes of fat, that take place during heat treatment. A row over of acids that specify on falsification of raw material is brought in addition. On the basis of analysis oils, that was used for preparation of the fats taken on research, were identifiedcoconut, peanut, soy and sunflower. The improvement of methodology of exception of fat is conducted from the prepared product. Basic maintenance of research folds an analysis changes of fatty acid composition, that take place after heat treatment. Research results expose, that to every type of fat the individual changes of fatty acid composition are inherent. This problem is small studied and requires more detailed.

Key words: gas chromatography, fatty-acid compound, food fats, oils, butter, margarine, tampering fat, oxidization, heat treatment, bakegoods

\section{Вступ}

Останнім часом гостро постало питання здорового раціонального харчування. Оскільки за останні роки виробники харчових продуктів, до складу яких входять тваринні жири та олії, все частіше замінюють частково або повністю жир, зазначений у рецептурі, на більш дешевий жир іншого складу чи нижчої якості (Nechaev, 2002; Kastornyh et al., 2003; Viktorova et al., 2006).

Вживання неякісних жирів з їжею сприяє розвитку серцево-судинних захворювань, саме тому визначення виду жиру в готовому продукті є актуальним питанням виявлення його фальсифікації.

Найчастіше відбувається фальсифікація товарів, які в своєму складі містять вершкове масло. Адже масло характеризується високими органолептичними властивостями: смаком, ароматом, консистенцією, кольором. Згідно з діючим ДСТУ на масло вершкове, додавання рослинних жирів в природному чи гідрогенізованому вигляді не дозволяється.

Найпоширенішим способом фальсифікації вершкового масла $\epsilon$ його часткова або повна заміна на маргарин. Мають місце і такі фальсифікації, як додавання кокосового, пальмового масла, арахісової, соняшникової та ін. олії, які попередньо пройшли гідрогенізацію (Jakovlev et al., 2000; Pavlova et al., 2006; Chmilenko et al., 2009).

\section{Матеріал і методи досліджень}

Використання сучасних технологій в масложировому виробництві ускладнює виявлення фальсифікатів. Класичні методи аналізу харчових продуктів вже не дозволяють точно та достовірно встановлювати підробки та їх склад. Визначення фальсифікації жиру в борошняних кондитерських виробах проводили, одним 3 сучасних методів капілярною газовою хроматографією. Для цього визначали жирнокислотний склад сировини, яка використовувалась, і його зміни уже в готовому продукті.

\section{Результати та їх обговорення}

Як контрольний (порівняльний) зразок використовували масло домашнє. Дослідження проводили 3 маслом селянським солодко вершковим 3 вмістом жиру 73\% та маргарин столовий «молочний» жирністю не менше $82 \%$. Дані жирнокислотного складу вище зазначених зразків наведено на рис. 1 .

3 даної діаграми видно, що для масла домашнього, крім основних кислот, характерна наявність гептадеценової, ейкозадієнової та арахідонової кислот. Для натурального масла характерний жирнокислотний склад, наведений для масла домашнього, наявність інших кислот свідчить про внесення різноманітних добавок.

Присутність в маслі «селянському» солодковершковому таких кислот, як: капринова, ундеканова, бегенова, - та збільшений відсотковий вміст лауринової, міристинової, стеаринової кислот свідчать про внесення кокосової олії.

3 жирнокислотного складу маргарину видно домішки арахісової або соєвої олії. Про це свідчить наявність арахінової, гондоїнової, ерукової кислот та підвіщений вміст лінолевої і ліноленової кислот.

Для визначення фальсифікації в готових виробах спочатку вилучають жир з продукту. Метод передбачає видалення жиру з наважки дослідного продукту (у нашому випадку - печива) способом настоювання з розчинником в колбі з притертою пробкою протягом певного проміжку часу. Розчин фільтрують, розчинник відганяють, залишок випарюють і проводять хроматографічний аналіз. Результати хроматографічного аналізу наведено на рис. 2. 


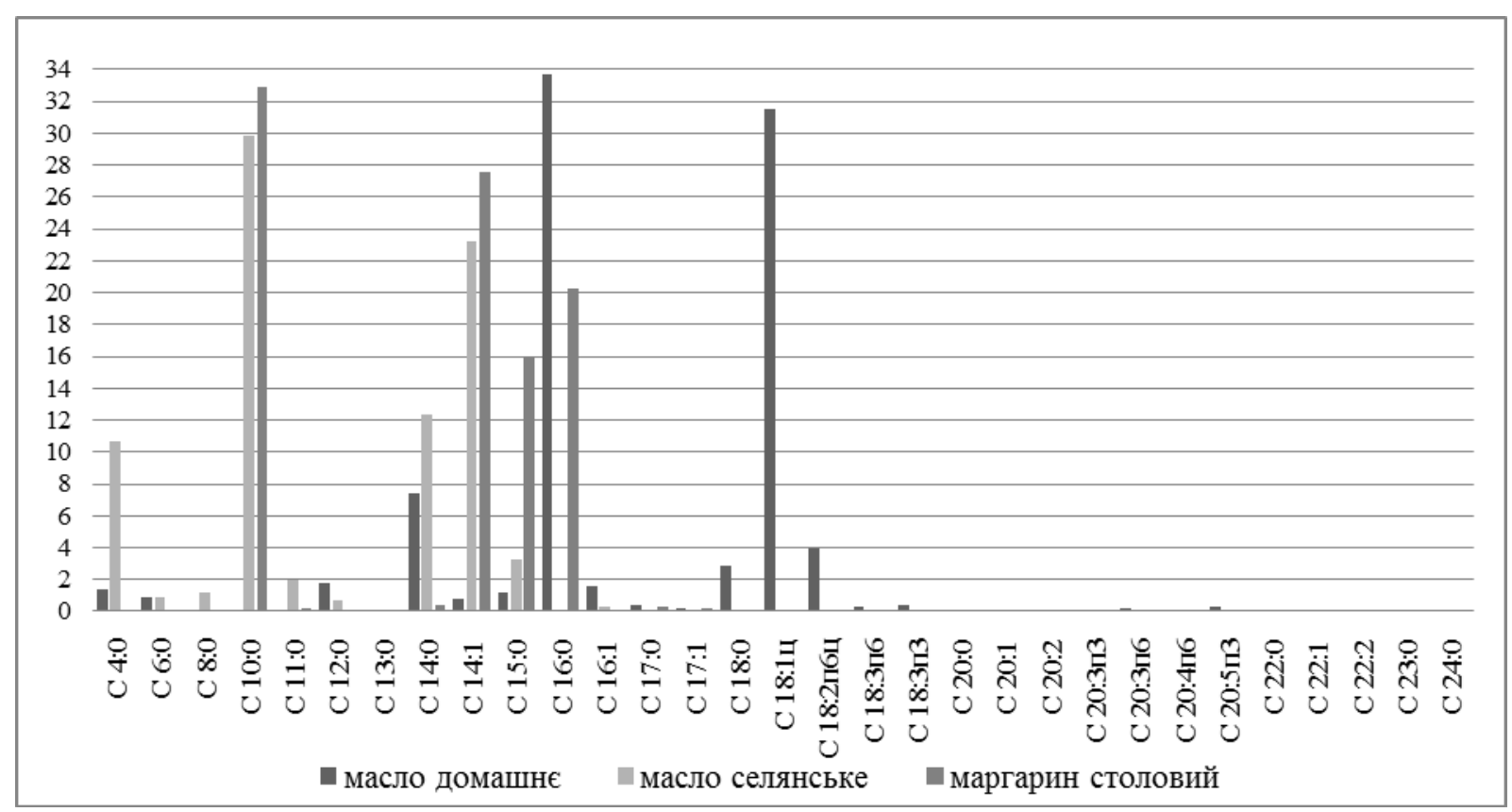

Рис. 1. Жирнокислотний склад досліджуваних видів жиру

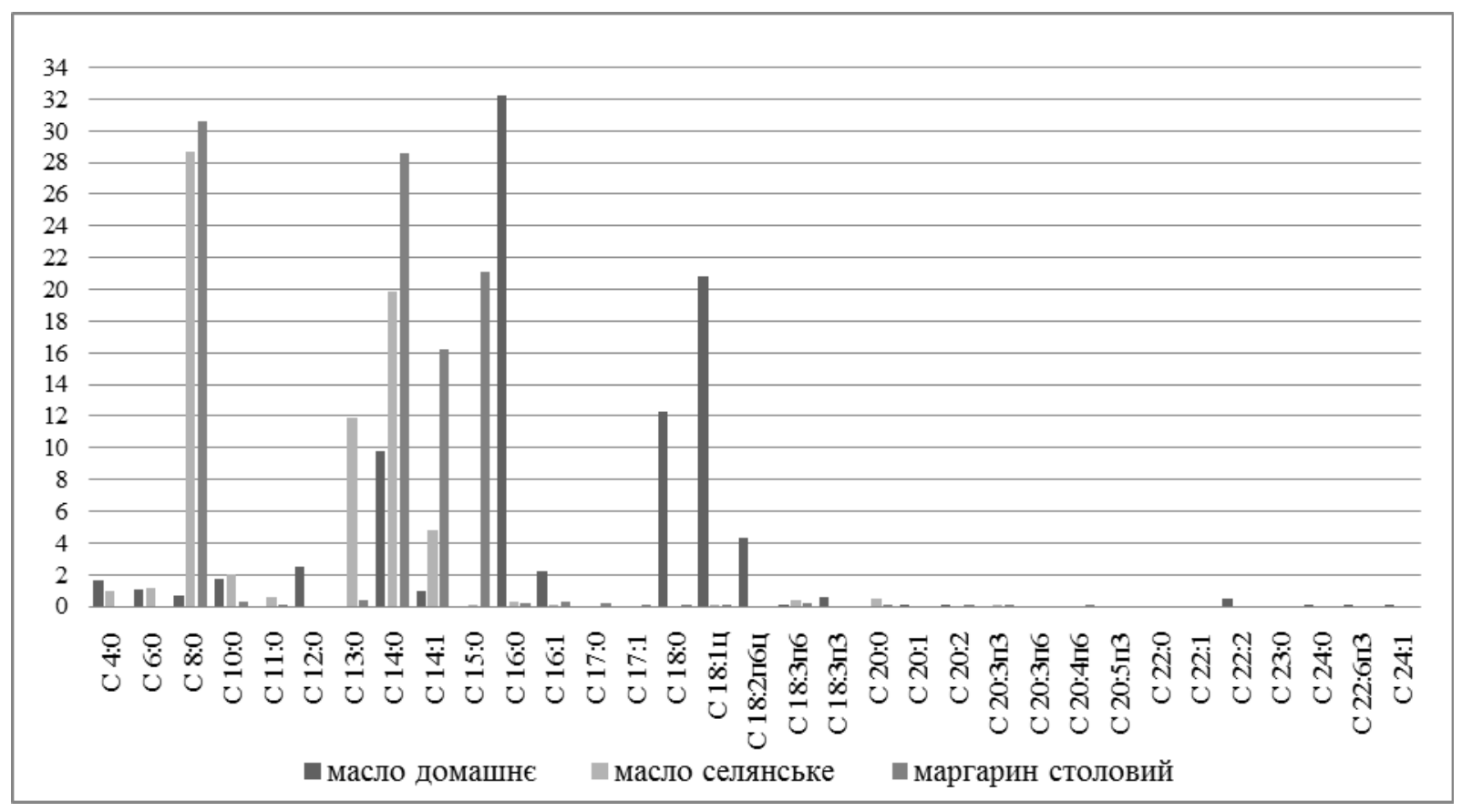

Рис. 2. Жирнокислотний склад різних видів жиру після термічної обробки

3 діаграми видно, що для масла домашнього характерна поява таких кислот як: каприлова, капронова, лігноцеринова, даказагексаєнова та нервонова кислоти в зв'язку з ізомеризацією та окисленням деяких кислот.

Жирнокислотний склад масла «селянського» солодковершкового після випікання також зазнав змін, але не таких значних, як в домашньому маслі. Це пов'язано $з$ проведенням певного термічних обробок за його виготовлення. Утворення арахінової, ейкозапентенової, ерукової кислот спричинене ізомеризацією інших кислот.
Зміни в жирнокислотному складі маргарину характеризуються деструкцією капронової, каприлової, лауринової кислот. Поява нервонової кислоти пов'язана з окисленням деяких кислот.

\section{Висновки}

Проаналізувавши жирнокислотний склад жиру, який вилучили 3 готових виробів, і виявивши такі кислоти як: капронова, ундеканова, арахінова, ейкозапентенова та ерукова, - можна стверджувати, що в даному жирі є домішки кокосової олії. Наявність ара- 
хінової, гондоїнової, ерукової кислот та підвіщений вміст лінолевої і ліноленової кислот свідчить про внесення арахісової або соєвої олії.

Перспективи подальших досліджень. В подальшому планується проводити вивчення жирнокислотного складу $з$ частковою заміною жиру. Проводити додаткові методи експрес-оцінки якості жиру та розробку додаткових критеріїв ідентифікації.

\section{Бібліографічні посилання}

Nechaev, A.P. (2002). Zhirovye produkty i zdorov'e. Materialy vtoroj mezhdunar. konf. «Maslozhirovoj kompleks Rossii. Novye aspekty razvitija». Mezhdunar. prom. akad., 3-6 ijunja. M.: Pishhepromizdat, 21-23 (in Russian).

Viktorova, E.V., Kulakova, S.N., Mihajlov, N.A., Gapparov, M.M. (2006). Jekspress-metod ocenki podlinnosti zhirovyh produktov, razrabotannyj na osnove komp'juternogo informacionnogo obespechenija. Voprosy pitanija, 75(6), 61-66 (in Russian).

Jakovlev. V.S., Kulikovskaja. T.S., Krapivkin. B.A. (2000). Gazohromatograficheskij analiz zhirnokislotnogo sostava slivochnogo masla. Molochnaja prom-st'. 1, 39-43 (in Russian).

Chmilenko, F.A., Minaeva, N.P., Sandomirskij, A.V., Sidrrova, L.P. (2009). Ustanovlenie fal'sifikacii molochnoj produkcii metodami gazovoj hromatografii. Metody i objekty himicheskogo analiza. 4(1), 60-66 (in Russian).

Kastornyh, M.S., Kuz'mina, V.A., Puchkova, Ju.S. (2003). Tovarovedenie i ekspertiza pishhevyh zhirov, moloka i molochnyh produktov. M.: Akademija (in Russian).

Pavlova, V.A., Ty`tarenko, L.D., Zaly`gina, V.D. (2006). Identy`fikaciya ta fal'sy`fikaciya prodovol`chy`x tovariv: Navchal`ny`j posibny`k. Ky`yiv: Centr navchal noyi literatury (in Ukrainian).

Стаття надійшла до редакиії 15.09.2016 